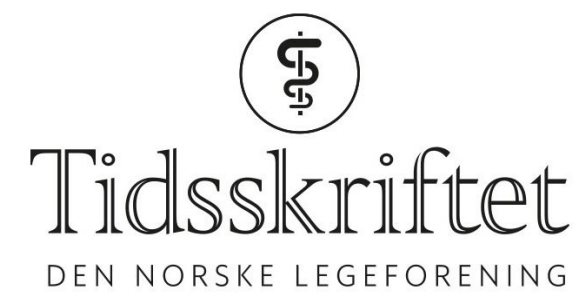

\title{
Ivar Helle
}

MINNEORD

JOHAN N. BRUUN

BJØRN MYRVANG

Vår gode kollega og venn Ivar Helle døde 16. april, 93 år gammel. Han ble født i Vestre Moland, og etter gjennomført skole og medisinstudium ble han cand.med. i Oslo i 1951. Deretter hadde han ulike legestillinger rundt omkring i landet frem til 1958, da han fikk utdanningsstilling ved Ullevål sykehus, hvor han hadde sin arbeidsdag frem til han ble pensjonist i 1994 .

Fra 1966 var Infeksjonsavdelingen ved Ullevål sykehus hans arbeidsplass, og her ble han spesialist $\mathrm{i}$ indremedisin og i infeksjonssykdommer, og spesiallege i tropesykdommer i 1971. Her gjorde han en stor og markant innsats gjennom nærmere 30 år, som kliniker og underviser, først og fremst fordi han etablerte fagområdet tropesykdommer ved sykehuset etter å ha gjennomført diplomkurs i tropemedisin ved Liverpool School of Hygiene and Tropical Medicine i 1966. Som spesiallege i fagfeltet var han i en årrekke sykehusets og landets fremste spesialist i importmedisin og tropesykdommer.

Fra begynnelsen av 1970-årene arrangerte han årlige kurs i tropesykdommer og parasittologi, og var en ypperlig læremester for kolleger over hele landet. Vi er mange som aldri glemmer Helles engasjerte undervisning, fremført i personlig stil med blid sørlandsdialekt. Hans virksomhet omfattet også undervisning for NORAD-personell før stasjonering i Afrika og andre verdensdeler. For å spre sine kunnskaper skrev han boken Råd for helse og sykdom under langtidsopphold $i$ utviklingsland.

Selv om tropesykdommer var hans spesialfelt, var han i en lengre periode sykehusets fremste spesialist i infeksjonssykdommer generelt, og han nøt stor respekt for sine kunnskaper og sitt kliniske skjønn også utenfor infeksjonsmedisinernes rekker. I vår tid er mange indremedisinere spesialister innen en snever gren av indremedisin, men Helle var en av få som hadde god oversikt over hele det indremedisinske fagfeltet. Hans kliniske skjønn var imponerende, samtidig som han hadde den gode klinikers nære og gode kontakt med pasientene. Hans innsats la grunnlaget for den sentrale rollen Infeksjonsmedisinsk avdeling har fått, både innen infeksjonsmedisin generelt og trope- og importmedisin spesielt. For denne virksomheten ble han tildelt Kongens fortjenstmedalje i gull.

Vi som skriver disse minneord, hadde Ivar Helle som kollega og lærer, og er takknemlige for hva han formidlet til oss av lærdom og væremåte.

På vegne av takknemlige kolleger 
Publisert: 26. juni 2018. Tidsskr Nor Legeforen. DOI: 10.4045/tidsskr.18.0358 (C) Tidsskrift for Den norske legeforening 2020. Lastet ned fra tidsskriftet.no 